Proceedings

\title{
Internationalization of SMEs and Effectuation: The Way Back and Forward ${ }^{\dagger}$
}

\author{
Hamza El Guili * and Driss Ferhane \\ The Department of Management, Marketing and Entrepreneurship, National School of Business and \\ Management, 90000 Tangier, Morocco; ferhane.driss@gmail.com \\ * Correspondence: hamza.el.guili@gmail.com; Tel.: +212-620-19-58-04 \\ + Presented at the 2th Entrepreneurship and Family Enterprise Research International Conference \\ (EFERIC2018), Edinburgh, United Kingdom, 27-29 June 2018.
}

Published: 15 November 2018

\begin{abstract}
Business growth is considered as one of the main topics of entrepreneurship research. Due to the increased interest on entrepreneurship, new theoretical perspectives have emerged to explain entrepreneurial behavior. One of these emergent theories is effectuation. It is widely known that entrepreneurs and owner-managers count on different decision-making logics during the internationalization of their ventures, including causal and effectual reasoning. Despite that the use of effectual reasoning has been generally linked to the early stages of the creation of a venture; it has recently been introduced to on the internationalization of SMEs research. Introduced by Sarasvathy (2001), effectuation logic is stated to grow in an unstable operating context where it is complicated to predict and in contrast, it is likely to unexpectedly respond to changes in the environment. Furthermore, it represents a typical shift in approaching entrepreneurship. In this theoretical paper, we first aim to highlight the evolution of the concept and the development of the effectuation theory within the literature. Furthermore, we explain the similarities and differences existing between causation and effectuation reasoning. Finally, we use the lens of effectuation to come up with an understanding of the internationalization of SMEs.
\end{abstract}

Keywords: effectuation; causation; internationalization; SME

\section{Introduction}

It is widely known that business growth is essential in the entrepreneurship research. Researchers in the this field have always seen that decision making models based on rationality are engaged by neoclassical economics [1]. Because the interest in entrepreneurship has increased, it has been noticed the emergence of new theoretical and relevant perspectives analyzing the entrepreneurial behavior [2]. In this regard, modern approaches, as effectuation [3] and bricolage [4], have commonly been known as emerging theories within the entrepreneurship research [5]. In fact, such approaches are in contradiction with the traditional and classic models of entrepreneurial behaviors. Economic thinking is recognized as being a vital factor of the traditional model of entrepreneurship. The traditional model usually describes the entrepreneurial actions of individuals within firms, by searching for fields/areas where the demand for a certain product or service surpasses its supply and discovering an entrepreneurial opportunity, before evaluating its exploiting options [6]. Then, the entrepreneur or the owner-manager decides to take action of establishing a venture, after choosing to capitalize on an existing opportunity, which creates at the end of the process, a return from the venture [2]. Other theoretical perspectives see that entrepreneurial action can be achieved toward a considerable number of routes to identify and take 
advantage of opportunities. It is in this sense that effectuation, which is considered as one of the most-cited emerging theories of entrepreneurship, has emerged [1].

\section{Effectuation: An Overview of the Concept's Evolution}

The "effectuation theory" was first introduced by Sarasvasthy (2001), to be an alternative approach to the "causation theory", which has been an existing entrepreneurial approach within the research on recognition and firm's development [1,3]. While it has found its roots in the entrepreneurship, effectuation may also be useful in other fields, such as strategy [7], marketing [8] and R\&D [9]. Effectuation gives an explanation to the individuals by building and starting new business activities despite the fact it was not their primary goal. Entrepreneurs take risks only to the degree to which they are willing to take losses and maintain the power of adaptation to changes, which is brought by the nature of the environment. Entrepreneurs seek new business opportunities appearing from the various changes and learned by doing $[3,10]$. Effectuation logic is more likely to grow in an uncertain environment, where prediction becomes difficult, as it allows to shift reactions in order to adapt to changes of the environment [11]. Furthermore, continuous learning is considered as being meaningful in the effectuation logic. Throughout continuous learning, changes in the environment necessitate that the individual/firm change and be willing to learn new and appropriate methods to rapidly respond to mutations [3]. What we know about effectuation is largely based on the solving problems methods [12], mentioned by uncertainty of Knight [13], the enactment of Weick [14], and the Marchian goal [15]. The entrepreneur launches the venture based on who he is, what he knows and whom he knows). The Figure 1 represents a dynamic model of effectuation that highlights the five principles of effectuation [11].

Expanding Cycle of Resources

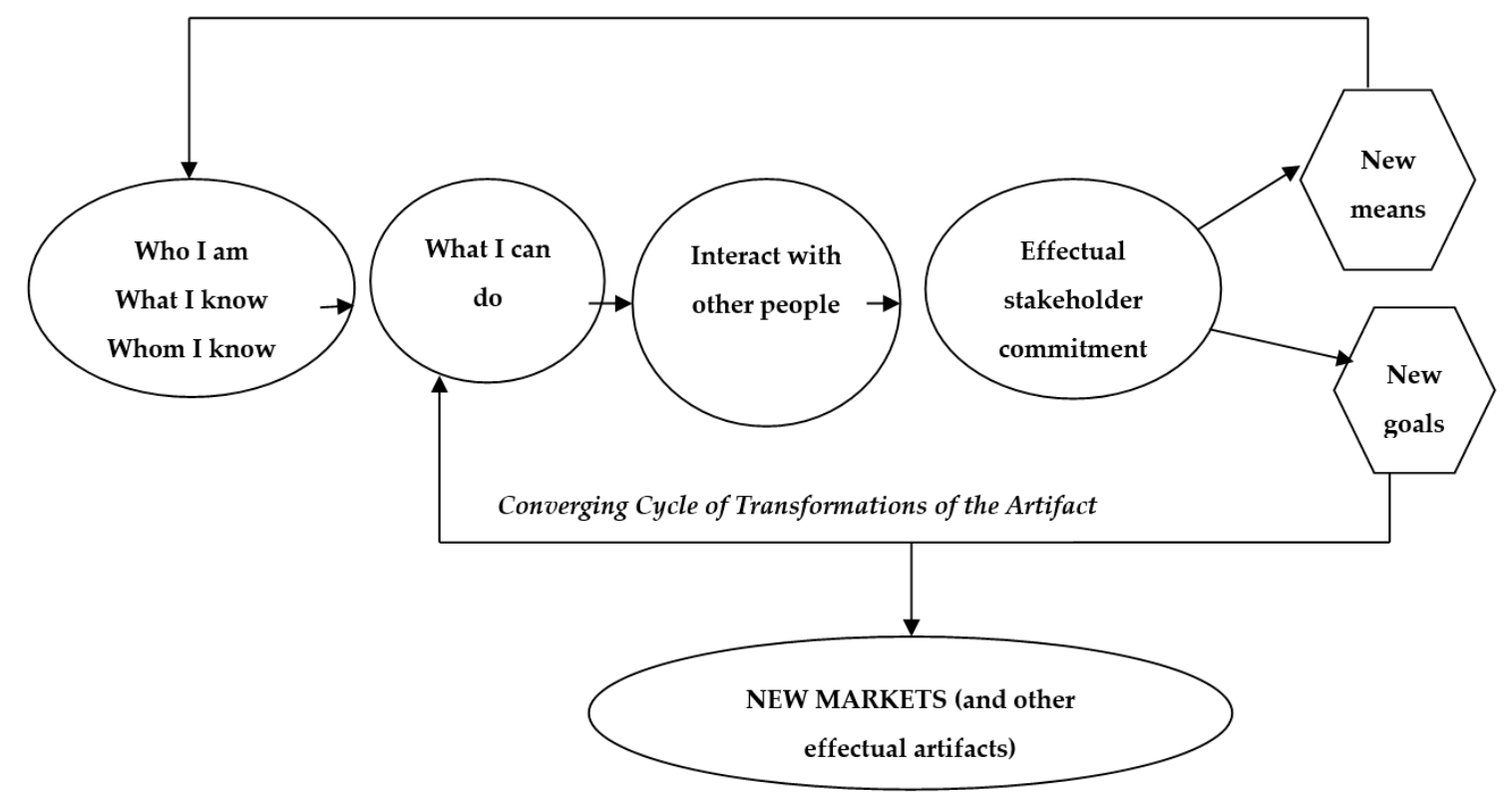

Figure 1. Dynamic Model of Effectuation [11].

\section{Effectuation Versus Causation: A Conceptual Review}

Causation and effectuation are both behavioral [3] and cognitive processes [1] used by entrepreneurs in opportunity identification and venture development. Effectuation is presented as a distinct process from causation $([3,10])$. In contrast to "causators" for instance, "effectuators" do not find new ideas, new contacts and new markets alone. Instead, effectuators go through this process with different members of a certain network [10]. Stakeholders carry new means and solutions into the organization. Thus, while bricoleurs for example do not aim to control the future, effectuators focus rather on the 'controllable' of uncertain future aspects [3]. In the causational approach, 
entrepreneurs focus on the visible features of an unclear future. There have been attempts [3] in order to draw a framework that opposes causation to effectuation considering goals, key decision parameters, reaction to uncertainty, and basis of exploitation (Table 1).

Table 1. Differences between causation and effectuation logics [16].

\begin{tabular}{ccc}
\hline & Causation & Effectuation \\
\hline Goals & Pre-defined & Emerging \\
Decisions parameters & Maximization of expected return & Affordable loss \\
Uncertainty & Planning/competitive analysis & Alliances \\
Basis of exploitation & Capabilities and resources & Environmental contingencies \\
\hline
\end{tabular}

\section{The Importance of Effectuation in the International Context}

It has been argued that SMEs (small and medium sized firms) are progressively internationalizing [17]. This has led to significant research into the phenomenon, with studies producing various research streams, such as international entrepreneurship stream. After the first studies on the role of effectuation in internationalization (e.g., [18]), there has been an increasing interest on empirical studies on the relevance of effectual process logic, used in decision-making related to the internationalization of ventures. Effectuation can be seen as a complement to studies that aimed to understand the internationalization process of SMEs with a holistic approach [19].

There is another research stream of internationalization through the effectuation. Several scholars have positioned the concept of effectuation within internationalization context (e.g., [19]). There has been an attempt to integrate the effectuation theory into the Uppsala model in an international case company [18]. While studies were undertaken on dynamics of decision-making during the internationalization process has of ventures, and emphasized the limited resources and capabilities of SMEs and the relevance of networks in overcoming these liabilities [20]. Practitioners argue that SMEs overcome their lack of resources by reinforcing their networks. While others [21], have concluded that entrepreneurs and owner-managers with limited resources, tend to network effectually with specific interested partners while entering foreign markets.

\section{Conclusions}

The purpose of this paper is to shed light on the literature on SMEs' internationalization processes using the effectuation and causation lens. There have been several attempts to explore and discover the power of effectuation concept within decision-making during ventures internationalization. Sarasvathy [3] argues that neither of the two logics is superior, because their effectiveness is primarily dependent on the problem space characteristics. Under conditions of risk, causal logic is more likely to be used, while during uncertainty contexts, effectual logic is more likely to be used. The two logics in the decision-making processes can coexist as they are configured in certain ways at different phases of venture's lifecycle. In the past years, it is known that empirical field studies are becoming the dominant form of effectuation research [22]. Moreover, previous studies [19] noticed that entrepreneurs are not more oriented to a specific type of logic. In contrast, the logic used depends on the characteristic of the internationalization decision. From their analysis, it becomes logic that the entrepreneurs start approaching their problems using causal logic.

In the future, we recommend using the lens of effectuation and causation to analyze why and how entrepreneurs or owner managers think, process, and make decisions to identify and exploit opportunities available in foreign markets. Thus, the use of how and why of entrepreneurs changes their decision logic related to internationalization over time, and therefore, contribute to the growing literature on effectuation. 


\section{References}

1. Perry, J.T.; Chandler, G.N.; Markova, G. Entrepreneurial effectuation: A review and suggestions for future research. Entrep. Theory Pract. 2012, 36, 837-861.

2. Fisher, G. Effectuation, causation, and bricolage: A behavioral comparison of emerging theories in entrepreneurship research. Entrep. Theory Pract. 2012, 36, 1019-1051.

3. Sarasvathy, S.D. Causation and effectuation: Toward a theoretical shift from economic inevitability to entrepreneurial contingency. Acad. Manag. Rev. 2001, 26, 243-263.

4. Baker, T.; Nelson, R.E. Creating something from nothing: Resource construction through entrepreneurial bricolage. Adm. Sci. Q. 2005, 50, 329-366.

5. Beckman, C.M., Eisenhardt, K., Kotha, S., Meyer, A., \& Rajagopalan. N. Technology entrepreneurship. Strateg. Entrep. J. 2010, 6, 89-93.

6. Shane, S.; Venkataraman, S. The promise of entrepreneurship as a field of research. Acad. Manag. Rev. 2000, 25, 217-226.

7. Wiltbank, R.; Dew, N.; Read, S.; Sarasvathy, S.D. What to do next? The case for non-predictive strategy. Strateg. Manag. J. 2006, 27, 981-998.

8. Read, S.; Dew, N.; Sarasvathy, S.D.; Song, M.; Wiltbank, R. Marketing under uncertainty: The logic of an effectual approach. J. Mark. 2009, 73, 1-18.

9. Brettel, M.; Mauer, R.; Engelen, A.; Küpper, D. Corporate effectuation: Entrepreneurial action and its impact on R\&D project performance. J. Bus. Ventur. 2012, 27, 167-184.

10. Sarasvathy, S.D. Effectuation: Elements of Entrepreneurial Orientation; Edward Elgar Publishing: Cheltenham, UK, 2008.

11. Sarasvathy, S.D.; Dew, N. Entrepreneurial logics for a technology of foolishness. Scand. J. Manag. 2005, 21, 385-406.

12. Dew, N.; Sarasvathy, S.D. What effectuation is not: Further development of an alternative to rational choice. In Proceedings of the Annual Meeting Academy Management, Denver, CO, USA, 11-14 August 2002.

13. Knight, F. Risk, Uncertainty, and Profit; Hart Schaffner and Marx prize essays no 31; Houghton Mifflin: Boston, MA, USA, 1921.

14. Weick, K.E. The Social Psychology of Organizing (Topics in Social Psychology Series); McGraw-Hill Humanit: New York, NY, USA, 1979.

15. March, J.G. The technology of foolishness. Ambiguity Choice Organ. 1976, 69, 81.

16. Chandler, G.N.; DeTienne, D.R.; McKelvie, A.; Mumford, T.V. Causation and effectuation processes: A validation study. J. Bus. Ventur. 2011, 26, 375-390.

17. Coviello, N.E.; McAuley, A. Internationalisation and the smaller firm: A review of contemporary empirical research. MIR Manag. Int. Rev. 1999, 223-256.

18. Sarasvathy, S.; Kumar, K.; York, J.G.; Bhagavatula, S. An effectual approach to international entrepreneurship: Overlaps, challenges, and provocative possibilities. Entrep. Theory Pract. 2014, 38, 71-93.

19. Kalinic, I.; Sarasvathy, S.D.; Forza, C. 'Expect the unexpected': Implications of effectual logic on the internationalization process. Int. Bus. Rev. 2014, 23, 635-647.

20. Harms, R.; Schiele, H. Antecedents and consequences of effectuation and causation in the international new venture creation process. J. Int. Entrep. 2012, 10, 95-116.

21. Galkina, T.; Chetty, S. Effectuation and networking of internationalizing SMEs. Manag. Int. Rev. 2015, 55, 647-676.

22. Matalamäki, M.J. Effectuation, an emerging theory of entrepreneurship-towards a mature stage of the development. J. Small Bus. Enterp. Dev. 2017, 24, 928-949.

(C) 2018 by the authors. Licensee MDPI, Basel, Switzerland. This article is an open access article distributed under the terms and conditions of the Creative Commons Attribution (CC BY) license (http://creativecommons.org/licenses/by/4.0/). 